\title{
Production, composition and processing of milk from ewes fed soybean seeds
}

\author{
Nivea Maria Brancacci Lopes Zeola ${ }^{1,5}$, Américo Garcia da Silva Sobrinho ${ }^{1,6}$, Carla Tiemi \\ Hatsumura ${ }^{2}$, Thiago Henrique Borghi ${ }^{3}$, Carlos Renato Viegas ${ }^{3}$, José Carlos Barbosa ${ }^{4}$
}

\author{
"Universidade Estadual Paulista "Júlio de Mesquita Filho", Faculdade de Ciências Agrárias e Veterinárias, Departamento de Zootecnia, Jaboticabal, SP, \\ Brasil. \\ 2 Universidade do Oeste Paulista, Presidente Prudente, SP, Brasil. \\ ${ }^{3}$ Universidade Estadual Paulista "Júlio de Mesquita Filho", Faculdade de Ciências Agrárias e Veterinárias, Programa de Pós-graduação em Zootecnia, \\ Jaboticabal, SP, Brasil. \\ " Universidade Estadual Paulista "Júlio de Mesquita Filho", Faculdade de Ciências Agrárias e Veterinárias, Departamento de Ciências Exatas, Jaboticabal, SP, \\ Brasil. \\ ${ }^{5}$ Fellowship grant by FAPESP \\ ${ }^{6}$ Fellowship grant by CNPq.
}

\begin{abstract}
The objective of this study was to evaluate production, chemical composition, and estimates of total solids and fatty acid profile of milk from 1/2 Lacaune $\times 1 / 2$ Ile de France ewes fed control and soybean seeds-supplemented diets. Additionally, Roquefort type cheese was also produced and subjected to sensory analysis. Twenty four $1 / 2$ Lacaune $\times$ 1/2 Ile de France ewes were divided into three groups and fed a control diet and diets containing 70 and $140 \mathrm{~g} \mathrm{~kg}^{-1} \mathrm{soybean}$ as fed, during the lactation period. The remainder milk was used to produce Roquefort cheese. The experimental design was completely randomized, with three treatments $\left(0,70\right.$, and $140 \mathrm{~g}$ of soybean $\mathrm{kg}^{-1}$ as fed) and eight repetitions. The diets did not affect significantly the performance $\left(56.72 \mathrm{~kg}\right.$ post-birth weight; $62.63 \mathrm{~kg}$ weight after 56 lactation days; $2.03 \mathrm{~kg}$ day ${ }^{-1}$ dry matter intake; $0.11 \mathrm{~kg}$ average daily weight gain), or milk production $\left(443.61 \mathrm{~mL} \mathrm{day}^{-1}\right)$, density $\left(1.035 \mathrm{~g} \mathrm{~mL}^{-1}\right)$, acidity $\left(19.33{ }^{\circ} \mathrm{D}\right)$, and $\mathrm{pH}$ (6.41) of lactating ewes. Milk chemical composition was (per $100 \mathrm{~g}$ of milk): $14.86 \mathrm{~g}$ total solids, $9.84 \mathrm{~g}$ solids not fat, $4.98 \mathrm{~g}$ protein, $4.14 \mathrm{~g}$ casein, $5.03 \mathrm{~g}$ fat, and $4.11 \mathrm{~g}$ lactose. Saturated $(72.07 \mathrm{~g} / 100 \mathrm{~g}$ of fat), monounsaturated $(21.48 \mathrm{~g} / 100 \mathrm{~g}$ of fat) and polyunsaturated $(6.37 \mathrm{~g} / 100 \mathrm{~g}$ of fat) fatty acids were not significantly different. However, the polyunsaturated linoleic acid was significantly different in the milk from ewes fed the diet containing $140 \mathrm{~g}$ of soybean $\mathrm{kg}^{-1}$ as fed (5.58 g/100 g of fat) compared with those fed the control diet and $70 \mathrm{~g}$ of soybean $\mathrm{kg}^{-1}$ as fed $(3.82 \mathrm{~g} / 100 \mathrm{~g}$ of fat). The Roquefort type cheese had excellent acceptance by the panel. The highest cheese yield was obtained with the milk from ewes fed diets containing $70 \mathrm{~g} \mathrm{~kg}^{-1}$ soybean as fed. A diet containing $140 \mathrm{~g} \mathrm{~kg}^{-1}$ soybean as fed is recommended as it leads to greater linoleic acid content in the ewes milk, improving the lipid fractions and nutritional quality of the milk.
\end{abstract}

Key Words: fatty acid profile, milk secretion, physicochemical parameters, Roquefort type cheese, sensory analysis

\section{Introduction}

The Brazilian dairy sheep industry is growing rapidly, although research in the area is still incipient. Even though lamb meat is currently the main focus, there is great interest in dairy sheep, an area that needs research and development of production processes, especially due to the high added value of its products (Emediato, 2007). The high fat content (5.5 to $8.5 \mathrm{~g}$ of fat $/ 100 \mathrm{~g}$ milk) of sheep milk gives a higher yield in cheese production compared to cow and goat milk, which has a positive impact on the industry and the producer, who may charge a differentiated price for this milk (Ochoa-Cordero et al., 2002).

Received September 22, 2014 and accepted March 9, 2015

Corresponding author: nivea.brancacci@ig.com.br

http://dx.doi.org/10.1590/S1806-92902015000400003

Copyright (@) 2015 Sociedade Brasileira de Zootecnia. This is an Open Access article distributed under the terms of the Creative Commons Attribution Non-Commercial License, which permits unrestricted non-commercial use, distribution, and reproduction in any medium, provided the original work is properly cited.
The Lacaune breed, originally from France, is able to produce $150-200 \mathrm{~kg}$ milk per lactation, an average of 1.5 liters daily with $8 \mathrm{~g}$ of fat $/ 100 \mathrm{~g}$ of milk, which is used for producing the Roquefort cheese. On the other hand, Ile de France breed, also originally from France, is suitable for meat production. They are precocious, productive, and easy to adapt to different climates and farming systems. The breeding of Lacaune and Ile de France sheep aims at producing a crossbreed sheep that combines the desirable characteristics of both breeds.

Soybeans added to the animal diet increase its energetic density, influencing milk production by increasing absorption of fat-soluble compounds and forming essential fatty acids, with different composition and quality. Urano et al. (2006) recommends including soybean at up to $14 \mathrm{~kg}^{-1}$ as dry matter, considering its cost relative to other ingredients.

The fatty acid composition of ruminant tissues is not much affected by the lipid composition of the diet, 
depending on the biohydrogenation of lipids by rumen microorganisms. However, because the ruminal saturation of unsaturated fatty acids in the diet is usually incomplete, the fatty acid composition of the diet may influence the milk fatty acid composition (Berchielli et al., 2006).

This study evaluates production, chemical composition, estimated total solids and fatty acid profile of milk from 1/2 Lacaune $\times 1 / 2$ Ile de France ewes fed control and soybean seeds-supplemented diets. Additionally, Roquefort type cheese was also produced and subjected to sensory analysis.

\section{Material and Methods}

This research was developed in the city of Jaboticabal, located in São Paulo, Brazil, with geographic coordinates latitude $21^{\circ} 14^{\prime} 05^{\prime \prime} \mathrm{S}$, longitude $48^{\circ} 17^{\prime} 09^{\prime \prime} \mathrm{W}$, altitude $615.01 \mathrm{~m}$, atmospheric pressure of $944.3 \mathrm{hPa}$, average temperature $22.2{ }^{\circ} \mathrm{C}$, relative humidity of $72.5 \%$, and precipitation $1453.4 \mathrm{~mm}$, following the guidelines set by the Ethics Committee on Animal Use (Protocol No. 011104/10). Safety of the Roquefort type cheese was determined by microbiological analysis performed according to Resolution RDC No. 12, from January 2, 2001, of the National Health Surveillance Agency. The analysis to determine somatic cell count, fat, protein, lactose, casein, total solids, and solids not fat of ewes' milk were performed in Piracicaba, SP, Brazil.

Fifty Ile de France sheep underwent estrus synchronization according to the protocol described by Roncoletta and Morani (2009), and were, subsequently, inseminated with semen from Lacaune sheep, the dairy breed. During pregnancy the Ile de France ewes grazed on Tifton- 85 pasture and were fed a diet with (per $100 \mathrm{~g}$ as fed) $14 \mathrm{~g}$ crude protein, containing $40 \mathrm{~g}$ corn silage and $60 \mathrm{~g}$ of concentrate, consisting of (per $100 \mathrm{~g}$ of concentrate) $60 \mathrm{~g}$ ground corn, $20 \mathrm{~g}$ wheat bran, $15 \mathrm{~g}$ soybean meal, and $5 \mathrm{~g}$ mineral mix.
Twenty-four crossbred ewes (1/2 Lacaune $\times 1 / 2$ Ile de France) were milked by mothers until they reached $15 \mathrm{~kg}$ body weight. To meet the nutritional requirements for growth, according to the NRC (2006), the ewes grazed on Tifton-85 grass until weaning, and were also supplied, in creep feeding, concentrate with (per $100 \mathrm{~g}$ of concentrate) $20 \mathrm{~g}$ crude protein, containing $60 \mathrm{~g}$ ground corn, $25 \mathrm{~g}$ soybean meal, $11.5 \mathrm{~g}$ wheat bran, $3.0 \mathrm{~g}$ dicalcium phosphate, and $0.5 \mathrm{~g}$ mineral mix. After weaning, the ewes were fed a diet with (per $100 \mathrm{~g}$ of diet) $18 \mathrm{~g}$ crude protein, consisting of $50 \mathrm{~g}$ sugarcane and $50 \mathrm{~g}$ concentrate, composed of $36.0 \mathrm{~g}$ ground corn, $61.0 \mathrm{~g}$ soybean meal, $2.6 \mathrm{~g}$ dicalcium phosphate, and $0.4 \mathrm{~g}$ of a mineral mix. At 10 months old, weighing approximately $40 \mathrm{~kg}$, the ewes were placed in a breeding station with the Ile de France ram, for 45 days. During the gestation period, the 24 ewes remained in a confinement shed populated at a density of $2.0 \mathrm{~m}^{2} / \mathrm{ewe}$. They were fed a diet with (per $100 \mathrm{~g}$ of diet) $14 \mathrm{~g}$ crude protein, containing $40 \mathrm{~g}$ corn silage, and $60 \mathrm{~g}$ concentrate, consisting of (per $100 \mathrm{~g}$ of concentrate) $60 \mathrm{~g}$ ground corn, $20 \mathrm{~g}$ wheat bran, $15 \mathrm{~g}$ soybean meal, and $5 \mathrm{~g}$ mineral mix. After giving birth, the twenty-four 1/2 Lacaune $\times 1 / 2$ Ile de France ewes were divided into three batches and fed the diets with and without soybean $(0,7$ and $14 \%)$, formulated according to the requirements of NRC (2006). The treatments were as follows (per $100 \mathrm{~g}$ of diet): $0 \%$ - $40 \mathrm{~g}$ sugarcane, $23.3 \mathrm{~g}$ corn, $24.6 \mathrm{~g}$ soybean meal, $9.9 \mathrm{~g}$ citrus pulp, and $2.2 \mathrm{~g}$ mineral mix; 7\% - 40 g sugarcane, $7 \mathrm{~g}$ soybean seeds, $22.2 \mathrm{~g}$ corn, $19.2 \mathrm{~g}$ soybean meal, $9.4 \mathrm{~g}$ citrus pulp, and $2.2 \mathrm{~g}$ mineral mix; and $14 \%$ - $40 \mathrm{~g}$ sugarcane, $14 \mathrm{~g}$ soybean seeds, $21.0 \mathrm{~g}$ corn, $14.0 \mathrm{~g}$ soybean meal, $8.8 \mathrm{~g}$ citrus pulp, and $2.2 \mathrm{~g}$ mineral mix (Tables 1 and 2).

Ewes were milked from the third to the 59th day postpartum, totaling eight weeks of lactation, following the methodology described by Doney et al. (1979) and Silva Sobrinho (1992), which consisted of injecting intramuscularly $0.5 \mathrm{~mL}$ oxytocin (5 IU) and subsequent milking three minutes later, until emptying the udder.

Table 1 - Chemical composition of diet ingredients $\left(\mathrm{g} \mathrm{kg}^{-1}\right.$ of DM)

\begin{tabular}{|c|c|c|c|c|c|}
\hline \multirow[b]{2}{*}{ Nutrient } & \multicolumn{5}{|c|}{ Ingredient } \\
\hline & Sugarcane & Soybeans & Corn & Soybean meal & Citrus pulp \\
\hline Dry matter $\left(\mathrm{g} \mathrm{kg}^{-1}\right)$ & 181.2 & 882.8 & 877.1 & 899.3 & 834.5 \\
\hline Organic matter $\left(\mathrm{g} \mathrm{kg}^{-1}\right)$ & 174.8 & 832.7 & 864.0 & 828.2 & 765.7 \\
\hline Mineral matter $\left(\mathrm{g} \mathrm{kg}^{-1}\right)$ & 6.4 & 50.1 & 13.1 & 71.1 & 68.8 \\
\hline Crude protein $\left(\mathrm{g} \mathrm{kg}^{-1}\right)$ & 7.6 & 276.5 & 66.2 & 466.2 & 62.0 \\
\hline Ether extract $\left(\mathrm{g} \mathrm{kg}^{-1}\right)$ & 2.1 & 126.2 & 48.2 & 24.0 & 16.8 \\
\hline Neutral detergent fiber $\left(\mathrm{g} \mathrm{kg}^{-1}\right)$ & 39.4 & 248.4 & 100.3 & 130.2 & 240.2 \\
\hline Acid detergent fiber $\left(\mathrm{g} \mathrm{kg}^{-1}\right)$ & 238.9 & 150.8 & 59.0 & 93.2 & 172.9 \\
\hline Total carbohydrate $\left(\mathrm{g} \mathrm{kg}^{-1}\right)$ & 983.9 & 547.2 & 872.5 & 438.7 & 852.4 \\
\hline Non-fiber carbohydrates $\left(\mathrm{g} \mathrm{kg}^{-1}\right)$ & 613.2 & 298.8 & 708.5 & 213.5 & 612.2 \\
\hline Gross energy (Mcal kg-1 of DM) & 07.7 & 44.4 & 40.2 & 43.3 & 36.5 \\
\hline
\end{tabular}


Then, the ewes were placed back in the pens for twentyfour hours, until the next oxytocin injection and subsequent milking. Weekly, during milking, $50 \mathrm{~mL}$ milk samples were collected and kept in the freezer until analysis. The laboratory analysis of the samples determined the chemical composition (protein, fat, minerals, lactose and casein), estimated total solids, solids not fat, somatic cell count, and the fatty acid profile according to the Fleischmann method described by Barbato and Perdigón (1998).

The atherogenicity (AI) and desaturase (DI) indices were used to evaluate the nutritional quality of the lipid fraction of milk from the fatty acid profile. The AI was estimated using the following formula: $\mathrm{AI}=[(\mathrm{C} 12: 0+(4$ $\times \mathrm{C} 14: 0)+\mathrm{C} 16: 0)] /\left(\sum\right.$ MUFA $+\sum$ PUFA $)$, in whcih C12:0, $\mathrm{C} 14: 0$ and $\mathrm{C} 16: 0$ are the lauric, myristic, and palmitic saturated fatty acids, respectively; MUFA, monounsaturated fatty acids; PUFA, polyunsaturated fatty acids; and DI, the monounsaturated fatty acids/saturated fatty acids ratio in milk (Ulbricht and Southgate, 1991).

The mug with dark background test was performed daily while the California Mastits Test (CMT), every 14 days, to evaluate udder health status throughout lactation and detect possible cases of subclinical mastitis.

Milking was performed at $08.00 \mathrm{~h}$ daily, during 56 days, using a DeLaval milking machine at a rate of 120 beats $/ \mathrm{min}$ and $36 \mathrm{kPa}$ vacuum level. The expressed milk was filtered, pasteurized $\left(65^{\circ} \mathrm{C}\right.$ for $\left.30 \mathrm{~min}\right)$, packaged in plastic bottles,

Table 2 - Ingredients and chemical compositions of ingredients in the experimental diets, expressed as dry matter (DM)

\begin{tabular}{|c|c|c|c|}
\hline \multirow[b]{2}{*}{ Ingredients ( $\mathrm{g} \mathrm{kg}^{-1}$ of $\left.\mathrm{DM}\right)$} & \multicolumn{3}{|c|}{$\begin{array}{c}\text { Content of soybeans } \\
\left(\mathrm{g} \mathrm{kg}^{-1} \text { as fed }\right)\end{array}$} \\
\hline & 0 & 70 & 140 \\
\hline Sugarcane & 400.0 & 400.0 & 40.0 \\
\hline Soybeans & 0.0 & 70.0 & 14.0 \\
\hline Corn & 233.0 & 222.0 & 21.0 \\
\hline Soybean meal & 246.0 & 192.0 & 14.0 \\
\hline Citrus pulp & 99.0 & 94.0 & 8.8 \\
\hline Mineral mix ${ }^{1}$ & 22.0 & 22.0 & 2.2 \\
\hline \multicolumn{4}{|l|}{ Chemical composition } \\
\hline Dry matter $\left(\mathrm{g} \mathrm{kg}^{-1}\right)$ & 580.7 & 580.1 & 579.6 \\
\hline Organic matter $\left(\mathrm{g} \mathrm{kg}^{-1}\right)$ & 550.8 & 551.0 & 551.3 \\
\hline Mineral matter $\left(\mathrm{g} \mathrm{kg}^{-1}\right)$ & 29.9 & 29.1 & 28.3 \\
\hline Crude protein $\left(\mathrm{g} \mathrm{kg}^{-1}\right)$ & 139.3 & 132.4 & 126.4 \\
\hline Ether extract ( $\mathrm{g} \mathrm{kg}^{-1}$ of $\left.\mathrm{DM}\right)$ & 19.6 & 26.6 & 33.5 \\
\hline Neutral detergent fiber $\left(\mathrm{g} \mathrm{kg}^{-1}\right.$ of $\left.\mathrm{DM}\right)$ & 226.9 & 235.0 & 243.0 \\
\hline Acid detergent fiber $\left(\mathrm{g} \mathrm{kg}^{-1}\right.$ of $\left.\mathrm{DM}\right)$ & 149.4 & 153.4 & 157.3 \\
\hline Total carbohydrates $\left(\mathrm{g} \mathrm{kg}^{-1} \text { of } \mathrm{DM}\right)^{2}$ & 789.2 & 789.9 & 789.8 \\
\hline Non-fiber carbohydrates $\left(\mathrm{g} \mathrm{kg}^{-1} \text { of } \mathrm{DM}\right)^{3}$ & 523.5 & 522.0 & 519.7 \\
\hline Gross energy (Mcal kg-1 DM) & 26.7 & 26.9 & 27.0 \\
\hline
\end{tabular}

Mineral mix: phosphorus - $50 \mathrm{~g}$; calcium - $150 \mathrm{~g}$; sodium - $100 \mathrm{~g}$, magnesium - $5 \mathrm{~g}$; sulfur - $25 \mathrm{~g}$; zinc - 1,500 mg; manganese - $500 \mathrm{mg}$; cobalt - $10 \mathrm{mg}$; iodine - $40 \mathrm{mg}$; selenium - $10 \mathrm{mg}$.

${ }^{2}$ Total carbohydrates $=100-(\% \mathrm{CP}+\%$ ether extract $+\%$ ash $)$

${ }^{3}$ Non-fiber carbohydrates $=$ total carbohydrates - neutral detergent fiber. and stored at $-15{ }^{\circ} \mathrm{C}$ in a freezer, for a maximum period of 30 days, for the production of the Roquefort type cheese.

To ensure good sanitary conditions, the milking equipment was sanitized daily at the end of activities. The process consisted of heating the water to $70{ }^{\circ} \mathrm{C}$, soaking the liners in sodium hydroxide and sodium hypochlorite alkaline solution $(25 \mathrm{~mL} / 10 \mathrm{~L}$ of water) for $10 \mathrm{~min}$ to remove fat and protein, and subsequently submerging them in aqueous acidic water solution (room temperature) with phosphoric and nitric acids ( $25 \mathrm{~mL} / 10 \mathrm{~L}$ of water) for $5 \mathrm{~min}$ to remove minerals.

The ewes were individually milked and the milk was cooled down to $15{ }^{\circ} \mathrm{C}$ to quantify milk production. Subsequently, the milk volume was measured using a graduated cylinder; density, with a milk-gauge and $250 \mathrm{~mL}$ beaker; acidity, by titration of $10 \mathrm{~mL}$ of milk using $0.1 \mathrm{~N}$ Dornic solution with $2 \mathrm{~g}$ of phenolphthalein indicator $/ 100 \mathrm{~g}$ of solution, in alcohol and expressed as degrees Dornic; and $\mathrm{pH}$, with a TESTO 205 digital $\mathrm{pHmeter}$ coupled to an immersion electrode (Instituto Adolfo Lutz, 2008).

Milk fat, protein, lactose, casein, total solids, and solids not fat were determined following the infrared methodology according to the International Dairy Federation (2000), while the somatic cells count used flow cytometry (International Dairy Federation, 2006) and mineral matter according to the methodologies described by the Adolfo Lutz Institute (2008). The equipment used for these analyses was a MilkoScan ${ }^{\mathrm{TM}}$ FT, from the FOSS Analytical company.

Before determining the fatty acids, milk total lipids were extracted through the cold technique described by Bligh and Dyer (1959), which removes the lipid phase of the sample, and data are expressed as area percentage of each fatty acid.

The design was completely randomized, with three treatments $\left(0,70\right.$, and $140 \mathrm{~g}$ of soybean $\mathrm{kg}^{-1}$ as fed) and eight replicates. The treatments were compared by orthogonal contrasts, using the SAS (Statistical Analysis System, version 8.0) software for the statistical analysis. For the sensory analysis of Roquefort type cheese, the experimental design was completely randomized, with three treatments $(0,70$, and $140 \mathrm{~g}$ of soybean $\mathrm{kg}^{-1}$ as fed) and 100 repetitions (tasters).

The thawed ewes milk was used to manufacture the Roquefort type cheese according to the flowchart proposed by Scholz (1997). The following ingredients were used: $\mathrm{CaCl}_{2}(50 \mathrm{ppm})$ at the rate of $50 \mathrm{~mL} / 100 \mathrm{~L}$ of milk; liquid rennet Aspergillus niger var. Awamori, Estrela ${ }^{\circledR}$, sufficient to coagulate the milk in $40 \mathrm{~min}$ at a temperature of $35^{\circ} \mathrm{C}$ and coagulating power 1:3000; homofermentative mesophilic starter cultures type O lyophilized, consisting of the species Lactococcus lactis subspecies lactis and 
Lactococcus lactis, subspecies cremoris (DVS 50U), Chr. Hansen Ind. and Com. Ltd., to be used directly in the tank, $10 \mathrm{~g}$ of sodium chloride/100 $\mathrm{g}$ and $1 \mathrm{~g}$ of sodium chloride/ 100 g. A pure culture of the mold species Penicillium roqueforti lyophilized (DVS 10U) was used in the amount recommended by the manufacturer $(0.016 \mathrm{~mL} / \mathrm{L}$ of milk); the lyophilized commercial cultures were type DVS (direct vat set). The cheese matured in the ripening chamber at 90 to $95 \%$ humidity, during 30 days, at $12{ }^{\circ} \mathrm{C}$, and further 90 days at $5{ }^{\circ} \mathrm{C}$.

Cheese yield was calculated in $\mathrm{L}$ of milk/ $\mathrm{kg}$ of cheese, using the following formula: $\mathrm{Y} \%=(\mathrm{CM} / \mathrm{MM}) \times 100$, in which $\mathrm{Y} \%=$ percentage yield; $\mathrm{CM}=$ cheese mass; and $\mathrm{MM}=$ milk mass.

Cheese sensory analysis consisted of an acceptance test performed by 100 tasters, who assessed the attributes of color, taste, texture, and overall acceptance using the 9-point hedonic scale, as follows: 1 - dislike extremely, 2 dislike very much, 3 - dislike moderately, 4 - dislike slightly, 5 - neither like nor dislike, 6 - like slightly, 7 - like moderately, 8 - like very much, and 9 - like extremely (Moraes, 1993).

\section{Results}

The results show that the diets did not affect significantly $(\mathrm{P}>0.05)$ the performance of lactating ewes. Average weight was $56.72 \mathrm{~kg}$ and $62.63 \mathrm{~kg}$ immediately after parturition and after the 56-day lactation period, respectively, for a dry matter intake of $2.03 \mathrm{~kg} / \mathrm{ewe} /$ day and an average daily weight gain of $0.11 \mathrm{~kg}$ (Table 3).

Likewise, density $\left(1.035 \mathrm{~g} \mathrm{~mL}^{-1}\right)$, acidity $\left(19.33^{\circ} \mathrm{D}\right)$ and $\mathrm{pH}$ (6.41) were not affected ( $\mathrm{P}>0.05)$. On the other hand, $\mathrm{pH}$ varied over time, and the milk became slightly acidic with the advance of lactation (6.35 at 42 and 56 days) (Table 4).

The diets did not affect significantly the chemical composition of milk, except for minerals, which were higher in the milk from ewes fed the diet containing $70 \mathrm{~g} \mathrm{~kg}^{-1}$ of soybeans as fed (5.14 $\mathrm{g}$ of minerals/100 $\mathrm{g}$ of milk) compared with those fed diet with $140 \mathrm{~g} \mathrm{~kg}^{-1}$ of soybeans as fed (4.45 of minerals $/ 100 \mathrm{~g}$ of milk). The levels of total solids, solids not fat, protein, casein, fat and lactose were 14.86 , $9.84,4.98,4.14,5.03$, and $4.11 \mathrm{~g} / 100 \mathrm{~g}$ of milk, respectively (Table 5).

Table 3 - Performance of 1/2 Lacaune $\times 1 / 2$ Ile de France ewes fed soybean seeds-supplemented diet

\begin{tabular}{|c|c|c|c|c|c|c|}
\hline \multirow[b]{2}{*}{ Variable } & \multicolumn{3}{|c|}{ Content of soybeans ( $\mathrm{g} \mathrm{kg}^{-1}$ as fed) } & \multirow[b]{2}{*}{ F test } & \multirow[b]{2}{*}{ P-value } & \multirow[b]{2}{*}{$\mathrm{CV}(\%)$} \\
\hline & 0 & 70 & 140 & & & \\
\hline WP (kg) & 58.29 & 57.59 & 54.28 & 0.36 & 0.7043 & 17.60 \\
\hline W56 (kg) & 65.38 & 60.38 & 62.13 & 0.44 & 0.6510 & 16.60 \\
\hline DMI $\left(\mathrm{kg} \mathrm{d}^{-1}\right)$ & 21.5 & 17.6 & 21.8 & 1.05 & 0.3690 & 127.90 \\
\hline ADWG (kg) & 0.13 & 0.05 & 0,14 & 2.28 & 0.1287 & 21.51 \\
\hline
\end{tabular}

WP - weight after parturition; W56 - weight at 56 days of lactation; DMI - dry matter intake; ADWG - average daily weight gain from parturition to 56 days of lactation; $\mathrm{CV}$ - coefficient of variation.

Table 4 - Production and physicochemical parameters of milk from 1/2 Lacaune $\times 1 / 2$ Ile de France ewes fed soybean seeds-supplemented diet

\begin{tabular}{|c|c|c|c|c|}
\hline & \multicolumn{4}{|c|}{ Parameter } \\
\hline & Milk production $\left(\mathrm{mL} \mathrm{day}{ }^{-1}\right)$ & Density $\left(\mathrm{g} \mathrm{mL}^{-1}\right)$ & Acidity $\left({ }^{\circ} \mathrm{D}\right)$ & $\mathrm{pH}$ \\
\hline \multicolumn{5}{|c|}{ Content of soybeans (C), $\mathrm{g} \mathrm{kg}^{-1}$ as fed } \\
\hline 0 & 509.29 & 1.034 & 18.09 & 6.42 \\
\hline 70 & 418.47 & 1.036 & 21.50 & 6.29 \\
\hline 140 & 400.47 & 1.035 & 18.41 & 6.51 \\
\hline F test & 0.54 & 2.18 & 2.70 & 2.59 \\
\hline P-value & 0.5913 & 0.1391 & 0.0916 & 0.1003 \\
\hline \multicolumn{5}{|l|}{ Evaluation days (D) } \\
\hline 14 & 496.52 & 1.035 & 18.74 & $6.49 \mathrm{a}$ \\
\hline 28 & 430.35 & 1.035 & 19.52 & $6.43 \mathrm{ab}$ \\
\hline 42 & 435.13 & 1.035 & 19.22 & $6.36 b$ \\
\hline 56 & 397.39 & 1.036 & 20.07 & $6.34 b$ \\
\hline F test & 2.08 & 1.21 & 0.49 & 5.19 \\
\hline P-value & 0.1122 & 0.3131 & 0.6924 & 0.0030 \\
\hline $\mathrm{F}$ test for $\mathrm{C} \times \mathrm{D}$ interaction & 0.81 & 0.49 & 0.79 & 0.48 \\
\hline P-value & 0.5654 & 0.8123 & 0.5835 & 0.8203 \\
\hline CV $(\%)$ & 29.98 & 0.20 & 21.27 & 2.13 \\
\hline
\end{tabular}

a, b - within the same factor, means followed by different letters in the column differ by Tukey's test.

$\mathrm{CV}$ - coefficient of variation. 
The inclusion of soybean in the diets did not affect significantly $(\mathrm{P}>0.05)$ the fatty acid levels. Among the saturated fatty acids, the highest levels were determined for palmitic acid (26.75 g/100 g of fat), followed by myristic (12.41 g/100 g of fat), capric (10.64 g/100 g of fat), and lauric (6.76 g/100 g of fat) acids. Except for capric acid, which is responsible for the characteristic odor of products derived from sheep, the other three have a hypercholesterolemic effect and are associated with the development of cardiovascular diseases. It is noteworthy that ewes fed the diet with $140 \mathrm{~g} \mathrm{~kg}^{-1}$ of soybeans as fed produced milk richer in linoleic acid $(5.58 \mathrm{~g} / 100 \mathrm{~g}$ of fat)

Table 5 - Composition of milk from 1/2 Lacaune $\times 1 / 2$ Ile de France ewes fed soybean seeds-supplemented diet

\begin{tabular}{|c|c|c|c|c|c|c|}
\hline \multirow[b]{2}{*}{ Variable } & \multicolumn{3}{|c|}{ Content of soybeans ( $\mathrm{g} \mathrm{kg}^{-1}$ as fed) } & \multirow[b]{2}{*}{ F test } & \multirow[b]{2}{*}{ P-value } & \multirow[b]{2}{*}{$\mathrm{CV}(\%)$} \\
\hline & 0 & 70 & 140 & & & \\
\hline Total solids (g/100 g) & 14.54 & 15.48 & 14.56 & 1.00 & 0.3850 & 10.13 \\
\hline Solids not fat $(\mathrm{g} / 100 \mathrm{~g})$ & 9.59 & 10.25 & 9.67 & 1.68 & 0.2114 & 7.85 \\
\hline Protein $(\mathrm{g} / 100 \mathrm{~g})$ & 4.93 & 5.07 & 4.95 & 0.24 & 0.7895 & 8.53 \\
\hline Casein $(\mathrm{g} / 100 \mathrm{~g})$ & 4.09 & 4.23 & 4.11 & 0.27 & 0.7627 & 9.83 \\
\hline Casein (g/100 $\mathrm{g}$ of protein) & 82.84 & 83.41 & 83.01 & 0.37 & 0.6951 & 1.59 \\
\hline Fat $(\mathrm{g} / 100 \mathrm{~g})$ & 4.95 & 5.24 & 4.89 & 0.28 & 0.7589 & 19.43 \\
\hline Minerals (g/100 g) & $4.68 \mathrm{a}$ & $5.14 \mathrm{a}$ & $4.45 \mathrm{ab}$ & 3.83 & 0.0389 & 10.65 \\
\hline Lactose $(\mathrm{g} / 100 \mathrm{~g})$ & 3.92 & 4.46 & 3.94 & 2.44 & 0.1129 & 13.34 \\
\hline Somatic cells $(\times 1000 / \mathrm{mL}$ milk $)$ & 168.71 & 145.75 & 203.00 & 0.72 & 0.4992 & 55.62 \\
\hline
\end{tabular}

$\mathrm{CV}$ - coefficient of variation.

Table 6 - Fatty acid profile (g/100 g) of milk from 1/2 Lacaune $\times 1 / 2$ Ile de France ewes fed soybean seeds-supplemented diet

\begin{tabular}{|c|c|c|c|c|c|c|}
\hline \multirow[b]{2}{*}{ Parameter (g/100 g) } & \multicolumn{3}{|c|}{ Content of soybeans ( $\mathrm{g} \mathrm{kg}^{-1}$ as fed) } & \multirow[b]{2}{*}{ F test } & \multirow[b]{2}{*}{ P-value } & \multirow[b]{2}{*}{$\mathrm{CV}(\%)$} \\
\hline & 0 & 70 & 140 & & & \\
\hline Saturated & 74.42 & 71.30 & 70.79 & 1.68 & 0.2121 & 5.69 \\
\hline C4: 0 (butyric acid) & 1.43 & 1.71 & 1.63 & 1.30 & 0.2958 & 21.52 \\
\hline C6: 0 (caproic) & 2.16 & 2.18 & 2.07 & 0.27 & 0.7680 & 14.83 \\
\hline C8: 0 (caprylic) & 3.05 & 2.92 & 2.76 & 1.10 & 0.3531 & 2.90 \\
\hline C10: 0 (capric) & 11.45 & 10.41 & 10.07 & 3.15 & 0.0646 & 10.37 \\
\hline C11: 0 (undecanoic) & 0.22 & 0.24 & 0.20 & 0.28 & 0.7590 & 45.35 \\
\hline C12: 0 (lauric) & 7.46 & 6.33 & 6.48 & 2.41 & 0.1158 & 15.95 \\
\hline C13: 0 (tridecanoic) & 0.18 & 0.19 & 0.20 & 0.11 & 0.8940 & 42.45 \\
\hline C14: 0 (myristic) & 13.55 & 11.73 & 11.96 & 2.18 & 0.1392 & 14.73 \\
\hline C15: 0 (pentadecanoic) & 1.10 & 1.19 & 1.15 & 0.14 & 0.8732 & 27.44 \\
\hline C16: 0 (palmitic) & 27.60 & 25.72 & 26.94 & 0.59 & 0.5642 & 12.79 \\
\hline C17: 0 (heptadecanoic) & 0.52 & 0.53 & 0.50 & 0.27 & 0.7647 & 15.87 \\
\hline C18: 0 (stearic) & 5.59 & 8.91 & 6.73 & 2.72 & 0.0899 & 39.41 \\
\hline C20: 0 (arachidic) & 0.08 & 0.10 & 0.08 & 0.23 & 0.7982 & 90.59 \\
\hline C22: 0 (behenic) & 0.02 & 0.02 & 0.02 & 0.02 & 0.9754 & 188.17 \\
\hline C23: 0 (tricosanoic) & 0.007 & 0.005 & 0.0 & 1.33 & 0.2873 & 224.46 \\
\hline C24: 0 (lignoceric) & 0.006 & 0.005 & 0.005 & 0.01 & 0.9861 & 180.38 \\
\hline Monounsaturated & 20.16 & 22.37 & 21.74 & 0.55 & 0.5829 & 19.29 \\
\hline C14: 1 (myristoleic) & 0.25 & 0.21 & 0.19 & 1.62 & 0.2223 & 27.53 \\
\hline C16: 1 (palmitoleic) & 1.38 & 1.13 & 1.12 & 3.64 & 0.0448 & 16.75 \\
\hline C17: 1 (heptadecenoico) & 0.29 & 0.22 & 0.22 & 3.68 & 0.0437 & 24.40 \\
\hline C18: 1n9c (oleic) & 16.19 & 18.33 & 17.79 & 0.65 & 0.5312 & 21.38 \\
\hline C18: 1 n7 (cis-vaccenic) & 1.95 & 2.35 & 2.26 & 0.49 & 0.6183 & 36.94 \\
\hline C20: $\ln 9$ (eicosenoic) & 0.07 & 0.09 & 0.08 & 0.79 & 0.4685 & 23.33 \\
\hline C24: 1n9 (nervonic) & $0.06 \mathrm{~b}$ & $0.08 \mathrm{ab}$ & $0.10 \mathrm{a}$ & 3.97 & 0.0353 & 29.03 \\
\hline Polyunsaturated & 5.27 & 6.26 & 7.45 & 2.52 & 0.1060 & 29.60 \\
\hline C18:2n6c (linoleic) & $3.74 b$ & $3.88 \mathrm{~b}$ & $5.58 \mathrm{a}$ & 5.28 & 0.0144 & 28.02 \\
\hline C18:3N6 ( $\gamma$-linolenic) & 0.13 & 0.10 & 0.11 & 1.49 & 0.2484 & 27.66 \\
\hline C18:3N3 ( $\alpha$-linolenic) & 0.21 & 0.31 & 0.37 & 1.60 & 0.2276 & 55.72 \\
\hline C18: 2C9, t11 (CLA - conjugated linoleic) & 0.68 & 0.70 & 0.85 & 0.57 & 0.5729 & 46.16 \\
\hline C18: 2Q10,c12 (conjugated linoleic) & 0.02 & 0.01 & 0.02 & 0.23 & 0.7934 & 109.65 \\
\hline C20:2 (eicosadienoic) & 0.03 & 0.02 & 0.03 & 0.20 & 0.8169 & 41.97 \\
\hline C20:3n6 (eicosatrienoic) & 0.03 & 0.05 & 0.05 & 2.17 & 0.1399 & 27.16 \\
\hline C20:4n6 (arachidonic) & 0.33 & 0.32 & 0.35 & 0.48 & 0.6263 & 22.11 \\
\hline C20: 5n3 (EPA-eicosapentaenoic) & 0.03 & 0.03 & 0.02 & 1.71 & 0.2061 & 30.90 \\
\hline C22: 4n6 (DTA-docosatetraenoic) & 0.05 & 0.05 & 0.06 & 0.93 & 0.4101 & 31.17 \\
\hline C22:6n3 (DHA - docosahexaenoic) & 0.003 & 0.014 & 0.005 & 1.88 & 0.1787 & 158.08 \\
\hline
\end{tabular}

$\mathrm{CV}$ - coefficient of variation. 
Table 7 - Desaturase and atherogenicity index of milk from 1/2 Lacaune $\times 1 / 2$ Ile de France ewes fed soybean seeds-supplemented diet

\begin{tabular}{lcccccc}
\hline & \multicolumn{3}{c}{ Content of soybeans $(\mathrm{g} \mathrm{kg}-1$ as fed $)$} & & F test & P-value \\
\cline { 2 - 4 } Parameter & 0 & 70 & 140 & & CV $(\%)$ \\
\hline DI C14:1/C14:0 & 0.018 & 0.017 & 0.016 & 0.92 & 0.4132 \\
DI C16:1/C16:0 & 0.050 & 0.044 & 0.042 & 1.66 & 0.2161 \\
DI C17:1/C17:0 & $0.555 \mathrm{a}$ & $0.413 \mathrm{bc}$ & $0.434 \mathrm{~b}$ & 7.80 & 0.0031 \\
AI & 3.68 & 2.80 & 2.91 & 2.13 & 0.1455 \\
UNSAT/SAT & 0.35 & 0.40 & 0.42 & 1.61 & 0.2248 \\
\hline
\end{tabular}

DI - desaturase index; AI - atherogenicity index; UNSAT/SAT - unsaturated:polyunsaturated fatty acid ratio; CV - coefficient of variation.

Table 8 - Yield and sensory analysis of Roquefort type cheese made from milk from ewes fed soybean seeds-supplemented diet

\begin{tabular}{|c|c|c|c|c|c|c|}
\hline \multirow[b]{2}{*}{ Variable } & \multicolumn{3}{|c|}{ Content of soybeans ( $\mathrm{g} \mathrm{kg}^{-1}$ as fed) } & \multirow[b]{2}{*}{ F test } & \multirow[b]{2}{*}{ P-value } & \multirow[b]{2}{*}{$\mathrm{CV}(\%)$} \\
\hline & 0 & 70 & 140 & & & \\
\hline Yield (g/100 g) & $14.15 b$ & $18.03 \mathrm{ab}$ & $16.85 b$ & 5.44 & 0.0130 & 14.06 \\
\hline Flavor & 7.46 & 7.77 & 7.15 & 0.90 & 0.4155 & 15.67 \\
\hline Consistency & 8.46 & 8.54 & 8.23 & 0.94 & 0.4001 & 7.08 \\
\hline Overall acceptance & 7.54 & 7.85 & 7.31 & 0.66 & 0.5226 & 15.84 \\
\hline
\end{tabular}

Cheese yield calculated after 120 ripening days expressed as $\mathrm{L}$ of milk/kg of cheese, using the following formula: $\% \mathrm{Y}=(\mathrm{CM} / \mathrm{MM}) \times 100$, in which $\% \mathrm{Y}=$ percentage yield; $\mathrm{CM}=$ cheese mass; and $\mathrm{MM}=$ milk mass .

$\mathrm{CV}$ - coefficient of variation.

compared with those fed the control diet ( $3.74 \mathrm{~g} / 100 \mathrm{~g}$ of fat) (Table 6).

No significant differences $(\mathrm{P}>0.05)$ were observed for the AI (3.13), unsaturated/saturated fatty acid ratio (0.39) and DI, except for the DI 17:1/C17:0, which was higher for the control diet (0.555) (Table 7).

The Roquefort type cheese made with ewes' milk had excellent acceptance by the taster panel, given that scores ranged from 7.15 to 8.54 for the evaluated sensory attributes in a structured 9-point hedonic scale. The milk from sheep fed the diet containing $70 \mathrm{~g} \mathrm{~kg}^{-1}$ of soybeans as fed had the best yield for cheese production (Table 8).

\section{Discussion}

Zhang et al. (2007) assessed the dry matter intake of Dorset sheep during six lactation weeks and found no effect $(\mathrm{P}>0.05)$ on the intake for diets with or without oilseeds (canola, sunflower, and linseed), with a higher value $\left(2.57 \mathrm{~kg} \mathrm{day}^{-1}\right)$ than that in this study.

During lactation, feed intake tends to increase gradually with the energy demand. However, this demand increases more rapidly than the dry matter intake in early lactation, and sheep are forced to use their body reserves during this period to produce milk, resulting in weight loss, which is related to the intensity of negative energy balance postpartum (Susin, 1996). According to the NRC (2006), for ewes weighing $50-60 \mathrm{~kg}$ in early lactation, the weight loss is $26-29 \mathrm{~g} \mathrm{day}^{-1}$, while dry matter intake ranges from 1.61 to $1.80 \mathrm{~kg} \mathrm{day}^{-1}$. This was not observed in this experiment, suggesting that the diets met the nutritional requirements of this phase and even resulted in weight gain (Table 3).

Likewise, Emediato et al. (2009) evaluated the performance of Bergamácia sheep fed a diet with $16 \mathrm{~g}$ crude protein/100 g of diet. These authors reported no weight loss during a 60 day lactation period, with weights of 54.27 and $62.78 \mathrm{~kg}$, immediately after parturition and after 60 days, respectively.

The results for density, acidity and $\mathrm{pH}$ were lower than those reported by Brito et al. (2006). These authors evaluated the milk from Lacaune sheep for up to 60 days of lactation and found a density of $1.037 \mathrm{~g} \mathrm{~mL}^{-1}$, acidity $24.02{ }^{\circ} \mathrm{D}$, and pH 6.64.

Souza et al. (2005) assessed the milk production of Corriedale sheep and observed a production peak in the lactation curve in the first weeks and subsequent decrease, with $635 \mathrm{~mL} /$ day in the third and fourth weeks, and $497 \mathrm{~mL}$ day $^{-1}$ between the fifth and eighth week of lactation. Mughetti et al. (2012) determined the milk production of Sarda sheep for 60 days and reported milk yield of $1.36 \mathrm{~L} \mathrm{day}^{-1}$ for sheep fed the control diet (without linseed) and $1.40 \mathrm{~L} \mathrm{day}^{-1}$ for those fed a diet containing linseed in the concentrate.

According to Church (1984) the lactation peak for sheep occurs on average between the 2 nd and 4th week of lactation. On the other hand, Susin (1996) reports the peak between the $3 \mathrm{rd}$ and 5 th week, while in this research there was no effect of days of lactation on milk production $\left(439.85 \mathrm{~mL} \mathrm{day}^{-1}\right)$. The peak was observed at 14 days of lactation $\left(496.52 \mathrm{~mL} \mathrm{day}^{-1}\right)$, close to the values reported by Emediato et al. (2009), for Bergamacia sheep, of 
$432.00 \mathrm{~mL} \mathrm{day}^{-1}$ at 14 days of lactation and $487.00 \mathrm{~mL}$ day $^{-1}$ after 56 days of lactation.

Ribeiro et al. (2007) evaluated milk production in Santa Ines ewes receiving oxytocin and reported a production peak at 35 days with $2.23 \mathrm{~L} \mathrm{day}^{-1}$, with overall average production throughout lactation of $0.82 \mathrm{~L} \mathrm{day}^{-1}$. Oilseeds are added to the diet supplied to dairy sheep to increase diet energy density while aiming at increasing milk production, as well. However, the results are not always the expected. The oil supplementation may increase (Mughetti et al., 2012; Tsiplakou and Zervas, 2013), have no effect (Zhang et al., 2006), or decrease (Almeida et al., 2013) milk production of small ruminants. The response to supplementation in dairy animals can be affected by factors such as the fat source, the amount provided, and lactation stage (NRC, 2001). The addition of moderate amounts of oil can increase milk production due to feeding efficiency, while high amounts can reduce feeding intake and, therefore, production due to depression of rumen function. In this study the inclusion levels of soybean did not affect the sheep dry matter intake.

Breeding programs have been crossing dairy breeds, such as Lacaune, with meat breeds, such as Ile de France, to produce crossbred females capable of higher milk production. It is expected that the crossbred F1 sheep resulting from the crossing will produce more milk than the maternal breeds; however, this was not observed in this study, given that $\mathrm{F} 1$ ewes produced on average $439.85 \mathrm{~mL}$ over the 56 lactation days (Table 4), which is lower than the production values observed for pure Ile de France sheep: $1.190 ; 1.310 ; 1.220$; and $890 \mathrm{~mL}$ at 14, 28, 42 and 56 days of lactation, respectively (Podleskis et al., 2005).

Ribeiro et al. (2007) evaluated the composition of milk from Santa Inês ewes that were receiving oxytocin and found higher values (Table 5) of total solids $(17.40 \mathrm{~g} / 100 \mathrm{~g}$ of milk), solids not fat (11.57 g/100 g of milk), and fat $(5.84 \mathrm{~g} / 100 \mathrm{~g}$ of milk). On the other hand, Mughetti et al. (2012) observed differences in the composition of milk from Santa Inês ewes fed the control and linseed-supplemented diets, with (per $100 \mathrm{~g}$ of milk) 5.91 and $6.10 \mathrm{~g}$ fat; 4.81 and $4.90 \mathrm{~g}$ protein; 3.74 and $3.83 \mathrm{~g}$ casein; and 4.77 and $4.86 \mathrm{~g}$ lactose in the milk from ewes fed the control diet (without linseed) and a diet with linseed, respectively.

Similarly, Zhang et al. (2006) reported an effect of oilseed on the composition of milk from 1/2 East Friesian $\times 1 / 2$ Lacaune sheep evaluated during eight weeks of lactation. They fed a diet without (control) and with oilseed (sunflower) and reported the contents (per $100 \mathrm{~g}$ of milk) of 16.93 and $16.58 \mathrm{~g}$ total solids; 4.76 and $4.65 \mathrm{~g}$ protein; 3.67 and $3.54 \mathrm{~g}$ fat; 6.67 and $6.41 \mathrm{~g}$ casein; and 4.65 and $4.67 \mathrm{~g}$ lactose, respectively.
Corroborating previous data, Almeida et al. (2013) investigated the effect of adding soybean oil $(30,60$, and $90 \mathrm{~g} /$ day) to the diet of Saanen goats, on the milk, and observed a decrease in total solids (12.31 to $11.52 \mathrm{~g} / 100 \mathrm{~g}$ of milk) and fat (3.31 to $2.41 \mathrm{~g} / 100 \mathrm{~g}$ of milk), as the oil supplied increased. This result can be explained by the decreasing feed intake by the goats due to the increasing oil content. Furthermore, the levels of protein, lactose, and fat solid extract were not significantly affected by the oil inclusion, with 3.26, 4.66 and $9.01 \mathrm{~g} / 100 \mathrm{~g}$ of milk, respectively.

In a study to assess the composition of milk from Karagouniko sheep fed a diet without and with $50 \mathrm{~g}$ of soybean oil $\mathrm{kg}^{-1}$ as fed, Zervas et al. (1998) found differences in fat (7.02 and $7.30 \mathrm{~g} / 100 \mathrm{~g}$ of milk), protein (5.68 and $5.94 \mathrm{~g} / 100 \mathrm{~g}$ of milk) and lactose (5.21 and $4.97 \mathrm{~g} / 100 \mathrm{~g}$ of milk) contents. It is noteworthy that the milk from the $1 / 2$ Lacaune $\times 1 / 2$ Ile de France crossbred of this experiment displayed a lower fat content $(5.03 \mathrm{~g} / 100 \mathrm{~g}$ of milk) than that commonly found in the milk from dairy breeds such as Lacaune and Sarda, which may contain up to 7.68 and $6.72 \mathrm{~g} / 100 \mathrm{~g}$ of milk, respectively (Nudda et al., 2002).

Regarding the inclusion of soybeans in the ewes' diet, to adjust the protein content to meet their nutritional requirements during the lactation period, the amount of soybean meal was reduced, so the diets showed similar protein levels (126.4 to $139.3 \mathrm{~g}$ crude protein $\mathrm{kg}^{-1}$ of dry matter), although these levels did not affect the protein content of the produced milk. The protein content of the diet may affect the amount and partition nitrogen compounds in milk and protein-deficient diets may reduce the protein content in the milk, while an increase in the dietary protein concentration may provide increased protein concentration in milk. To optimize the use of dietary nitrogen, the diet must be balanced for energy and protein, ensuring the ruminal degradation process of feeds, and this balancing will provide maximum bacterial growth per unit of fermented dry matter, with lower losses of urinary energy and nitrogen, thereby improving the use of dietary nitrogen for the milk casein synthesis (Nudda et al., 2004). Milk proteins result partly from the synthesis (from free amino acids) and filtration of the blood plasma. Albumin and casein are not present in the blood and therefore must be synthesized from blood precursors; proteins are subdivided into casein, which represent $80 \%$ of the total protein and serum protein represented by albumin, $\alpha$-lactalbumin, $\beta$-lactoglobulin, immunoglobulins and protease-peptone, totaling the remaining 20\% (Tronco, 2013). The somatic cell count in the milk $\left(172.48 \times 10^{3}\right)$ showed that the ewes' mammary glands were healthy during lactation, ensuring 
the sanitary quality of the milk, as this value was lower than $0.5 \times 10^{6}$, which indicates absence of mastitis in sheep, according Fragkou et al. (2014).

The profile of the fats present in the milk from ruminants differs from the profile of the fat consumed by the animal in the diet. This is due to the rate and extent of ruminal biohydrogenation process, which generates intermediary products, such as conjugated linoleic acid (CLA), which is beneficial to human health (Gómez-Córtes et al., 2008). In this study, the CLA content increased in the milk from ewes fed soybeans in their diets $(0.85 \mathrm{~g} / 100 \mathrm{~g})$ compared with those fed the control $(0.68 \mathrm{~g} / 100 \mathrm{~g})$ (Table 6).

Castro et al. (2009) reported that feeding diets supplemented with oilseeds (sunflower and palm oil) affected milk atherogenicity index. The milk from sheep fed sunflower oil displayed lower AI (2.81) than those fed diets with palm oil (3.10), which are closer to the values of this study. Furthermore, the values of C14:1/C14:0 and $\mathrm{C} 16: 1 / \mathrm{C} 16: 0$ were higher in the milk from sheep that received palm oil in their diets: 0.036 and 0.035 , respectively.

It is noteworthy that the lower the atherogenicity index, the better the food from the nutritional viewpoint of the lipid fraction. The AI is given by the percentage of lauric, myristic, and palmitic saturated fatty acids in relation to mono- and polyunsaturated acids. Likewise, the desaturase index is given by the ratio of monounsaturated to the saturated fatty acids in the milk (Ulbricht and Southgate, 1991). The activity of the $\Delta^{9}$-desaturase enzyme on the vaccenic acid in the mammary gland originates from the action of the ruminal microbiota on dietary unsaturated fatty acids, especially linoleic and linolenic acids, and is responsible for approximately $78 \%$ of the CLA in milk.

There is a growing interest in increasing the concentration of CLA in the milk from ruminants. To this end, in to order to clarify the $\Delta^{9}$-desaturase activity, Bauman and Lock (2006) proposed to evaluate the relationship between few cis 9 unsaturated fatty acids (C10:1, C12:1, $\mathrm{C} 14: 1, \mathrm{C} 16: 1, \mathrm{C} 18: 1$, and $\mathrm{C} 18: 2 \mathrm{c} 9 \mathrm{t11})$ and the isomers which give rise to it (C10:0, C12:0, C14:0, C16:0, C18:0, and C18:0 t11). According to Griinari et al. (2000), the DI given by the $\mathrm{C} 14: 1 / \mathrm{C} 14: 0$ ratio (monounsaturated meristoleic/saturated myristic fatty acids) best represents the activity of the $\Delta^{9}$-desaturase enzyme. C14:0 originates from the synthesis on this tissue and, consequently, almost all the cis double bond inserted at carbon 9 of the $\mathrm{C} 14: 1$ results from this enzyme activity.

Ribeiro et al. (2007) produced Roquefort type cheese matured for 90 days, using the milk from Santa Inês ewes, and reported yield of $16.70 \mathrm{~g} / 100 \mathrm{~g}$ of milk, a value close to those observed in this study (Table 8). Similarly, Zhang et al. (2006) manufactured cheese with milk from 1/2 East Friesian $\times 1 / 2$ Lacaune sheep fed diets containing linseed and sunflower. These authors reported yield of $17.04 \mathrm{~g} / 100 \mathrm{~g}$ of milk from ewe fed control and linseed-supplemented diet, and $16.36 \mathrm{~g} / 100 \mathrm{~g}$ of milk for the diet with sunflower seeds.

Cheese yield is associated with the content of casein and fat; therefore, it can be inferred that milk with high protein content increases cheese yield (Bencini and Pulina, 1997). In this study the milk from ewes fed diets with $70 \mathrm{~g}$ of soybean $\mathrm{kg}^{-1}$ as fed provided higher cheese yield, although no differences were recorded in the protein content of the milk.

Sheep milk is rich in fat ( $5.03 \mathrm{~g} / 100 \mathrm{~g}$ of milk), and this trait increases the cheese yield considerably as compared with the milk from cows and goats (Branciari et al., 2012). The cheese yield was $18.03 \mathrm{~g} / 100 \mathrm{~g}$ of milk for ewes fed the diet with $70 \mathrm{~g}$ of soybean $\mathrm{kg}^{-1}$ as fed, while no difference was observed between the yields of cheese prepared with milk from sheep fed the control and the $140 \mathrm{~g}$ of soybean $\mathrm{kg}^{-1}$ as fed-supplemented diet (15.5 g/100 $\mathrm{g}$ of milk).

\section{Conclusions}

Addition of soybean seeds to the diet of lactating ewes results in milk with adequate physicochemical parameters and cheese yield. Therefore, soybeans are a source of unsaturated fat that can be added to the diet fed to females during lactation, the postpartum period of negative energy balance. A diet with $140 \mathrm{~g}$ of soybean $\mathrm{kg}^{-1}$ as fed is recommended for lactating ewes, as it leads to sheep milk with higher content of (polyunsaturated) linoleic acid, improving the nutritional qualities and the lipid fractions of the milk.

\section{Acknowledgments}

Thanks are due to the São Paulo Research Foundation (FAPESP) for the financial support and the fellowship.

\section{References}

Almeida, O. C.; Pires, A. V.; Susin, I.; Gentil, R. S.; Mendes, C. Q.; Queiroz, M. A. A.; Ferreira, E.M. and Eastridge, M. L. 2013. Milk fatty acids profile and arterial blood milk fat precursors concentration of dairy goats fed increasing dosses of soybean oil. Small Ruminant Research 114:152-160.

Barbato, G. and Perdigón, F. 1998. Razas, registros e reproducción y mejora. p.9-16. In: Curso a distancia en leche ovina. Modulo1, unidade temática 2. 1st ed. Barbato, G. and Perdigón, F., eds. Faculdad de Veterinaria, Montevideo.

Bauman, D. E. and Lock, A. L. 2006. Conjugated linolic acid: biosynthesis ans nutritional significance. p.93-136. In: Advanced 
dairy chemistry. 1st ed. Fox, P. F. and McSweeney, P. H. L., eds. Springer, New York.

Bencini, R. and Pulina, G. 1997. The quality of sheep milk: a review. Wool Technology Sheep Breeding 45:182-220.

Berchielli, T. T.; Pires, A. V. and Oliveira, S. G. 2006. Nutrição de ruminantes. 1.ed. Funep, Jaboticabal.

Bligh, E. G. and Dyer, W. J. 1959. A rapid method of total lipid extraction and purification. Canadian Journal of Biochemistry Physiology 37:911-917.

Branciari, R.; Valiani, A.; Trabalza-Marinucci, M.; Miraglia, D.; Ranucci, D.; Acuti, G.; Esposto, S. and Mughetti, L. 2012. Consumer acceptability of ovine cheese from ewes fed extruded linseed-enriched diets. Small Ruminant Research 106:43-48.

Brito, M. A.; González, F. D.; Ribeiro, L. A.; Campos, R.; Lacerda, L.; Barbosa, P. R. and Bergmann, G. 2006. Composição do sangue e do leite em ovinos leiteiros do sul do Brasil: variações na gestação e na lactação. Ciência Rural 36:942-948.

Castro, T.; Manso, T.; Jimeno, V.; Del Alamo, M. and Mantecón, A. R. 2009. Effects of dietary sources of vegetable fats on performance of dairy ewes and conjugated linoleic acid (CLA) in milk. Small Ruminant Research 84:47-53.

Church, D. C. 1984. Alimentos y alimentacion del ganado. 7th ed. Hemisferio Sur, Montevideo.

Doney, J. M.; Peart, J. N. and Smith, W. F. 1979. A consideration of the techniques for estimation of milk yield by suckled sheep and a comparison of estimates obtained by two methods in relation to the effect of breed, level of production and stage of lactation. Journal of Animal Science 92:123-132.

Emediato, R. M. S. 2007. Efeito da gordura protegida sobre parâmetros produtivos de ovelhas da raça Bergamácia e na elaboração de queijos. Dissertação (M.Sc.). Universidade Estadual Paulista, Botucatu.

Emediato, R. M. S.; Siqueira, E. R.; Stradiotto, M. M.; Maestá, S. A. and Gonçalves, H. C. 2009. Desempenho de ovelhas da raça Bergamácia alimentadas com dieta contendo gordura protegida. Revista Brasileira de Zootecnia 38:1812-1818.

Fragkou, I. A.; Boscos, C. M. and Fthenakis, G. C. 2014. Diagnosis of clinical or subclinical mastitis in ewes. Small Ruminant Research 118:86-92.

Gómez-Córtes, P.; Frutos, P. and Mantecón, A. R. 2008. Milk production, conjugated linoleic acid content, and in vitro ruminal fermentation in response to high levels of soybean oil in dairy ewe diet. Journal of Dairy Science 90:1560-1569.

Griinari, J. M.; Corl, B. A. and Lacy, S. H. 2000. Conjugated linoleic acid is synthesized endogenously in lactating dairy coes by $\Delta^{9}$-dessaturase. Journal of Nutrition 130:2285-2291.

IAL - Instituto Adolfo Lutz. 2008. Normas Analíticas do Instituto Adolfo Lutz. Métodos físico-químicos para análise de alimentos. Imesp, São Paulo.

IDF - International Dairy Federation. 2000. Determination of milkfat, protein and lactose content - guidance on the operation of midinfrared intruments. IDF, Brussels.

IDF - International Dairy Federation. 2006. Milk - Enumeration of somatic cells. IDF, Brussels.

Moraes, M. A. C. 1993. Métodos para avaliação sensorial dos alimentos. 1.ed. Editora da Unicamp, Campinas.

Mughetti, L.; Sinesio, F.; Acuti, G.; Antonini, C.; Moneta, E.; Peparaio, M. and Trabalza-Marinucci, M. 2012. Integration of extruded linseed into dairy sheeo diets: Effects on milk composition and quality and sensorial properties of pecorino cheese. Animal Feed Science and Technology 178:27-39.
NRC - National Research Council. 2001. Nutrient requirements of dairy cattle. National Academy Press, Washington.

NRC - National Research Council. 2006. Nutrient requirements of small ruminants. National Academy Press, Washington.

Nudda, A.; Battacone, G.; Bencini, R. and Pulina, G. 2004. Nutritional and milk quality. p.129-150. In: Dairy sheep nutrition. 1st ed. Pulina, G. and Bencini, R., eds. CABI, Oxsfordshire.

Nudda, A.; Bencini, R.; Mijatovic, S. and Pulina, G. 2002. The yield and composition of milk in Sarda, Awassi and Merino sheep milked unilaterally at different frequencies. Journal of Dairy Science 85:2879-2884.

Ochoa-Cordero, M. A.; Hernández, G. T. and Ochoa-Alfaro, A. E. 2002. Milk yield and composition of Rambouillet ewes under intensive managment. Small Ruminant Research 43:269-274.

Podleskis, M. R.; Ribeiro, E. L. A.; Rocha, M. A.; Silva, L. D. F.; Mizubuti, I. Y.; Mori, R. M.; Ferreira, D. O. L. and Casimiro, T. R. 2005. Milk production of Hampshire Down and Ile de France ewes up to 84 days of lactation. Semina 26:117-124.

Ribeiro, L. C.; Pérez, J. R. O.; Carvalho, P. H. A.; Fonseca e Silva, F.; Muniz, J. A.; Oliveira Júnior, G. M. and Souza, N. V. 2007. Produção, composição e rendimento em queijo do leite de ovelhas Santa Inês tratadas com ocitocina. Revista Brasileira de Zootecnia 36:438-444.

Roncoletta, M. and Morani, E. S. C. 2009. Manual do inseminador em ovinos e caprinos. Intervet, Jaboticabal.

Scholz, W. 1997. Elaboración de quesos de oveja y de cabra. Acribia, Zaragosa.

Silva Sobrinho, A. G. 1992. Produccion y composicion quimica de la leche mediante metodos doble pesada y oxitocina en ovejas Manchegas tipos de parto simple y doble. Post Doctorate. Universidad de Cordoba, Cordoba, Espanha.

Souza, A. C. K. O.; Osório, M. T. M.; Osório, J. C. S.; Oliveira, J. C. S.; Vaz, N. M.; Souza, C. M. S.; Souza, M. and Corrêa, G. F. 2005. Produção, composição química e características físicas do leite de ovinos da raça Corriedale. Revista Brasileira de Agrociência 11:73-77.

Susin, I. 1996. Exigências nutricionais de ovinos e estratégias de alimentação. p.119-141. In: Nutrição de ovinos. 1.ed. Silva Sobrinho, A. G.; Batista, A. M. V. and Siqueira, E. R., eds. Funep, Jaboticabal.

Tronco, V. M. 2013. Manual para inspeção da qualidade do leite. 5.ed. Editora da UFSM, Santa Maria.

Tsiplakou, E. and Zervas, G. 2013. The effect of fish and soybean oil inclusion in goat diet on their milk and plasma fatty acid profile. Livestock Science 155:236-243.

Ulbricht, T. L. V. and Southgate, D. A. T. 1991. Coronary heart disease: seven dietary factors. Lancet 338:985-992.

Urano, F. S.; Vaz Pires, A. and Susin, I. 2006. Desempenho e características da carcaça de cordeiros confinados alimentados com grãos de soja. Pesquisa Agropecuária Brasileira 41:1525-1530.

Zervas, G.; Fegeros, K.; Koytsotolis, K.; Goulas, C. and Mantzios, A. 1998. Soy hulls as a replacement for maize in lactating dairy ewe diets with or without dietary fat supplements. Animal Feed Science and Technology 76:65-75.

Zhang, R. H.; Mustafa, A. F. and Zhao, X. 2006. Effects of feeding oilseeds rich in linoleic and linolenic fatty acids to lactating ewes on cheese yield and on fatty acid composition of milk and cheese. Animal Feed Science and Technology 127:220-233.

Zhang, R. H.; Mustafa, A. F. and Zhao, X. 2007. Effects of feeding oilseeds on nutrient utilization by lactating ewes. Small Ruminant Research 67:307-311. 